\title{
Relationships between broodiness expression laying persistency and concentrations of hormones during the first productive period in turkey hens (Meleagris gallopavo)*
}

\author{
D Guémené, JB Williams \\ INRA-Tours, Station de Recherches Avicoles, 37380 Nouzilly, France
}

(Received 3 June 1993; accepted 26 May 1994)

\begin{abstract}
Summary - The changes in egg production, in broodiness index and in plasma concentrations of LH, prolactin, œestradiol and progesterone were monitored throughout the first period of laying in turkey hens. The hens were subsequently classified according to their ability to express broodiness $(33 \%)$ and their laying persistency; $25 \%$ were out-of-lay by the end of the experiment. A high percentage $(67 \%)$ of the hens that went out-of-lay had previously been identified as broody. Altogether, a significant $(p<$ 0.05 ) physiological stage effect was found when comparing prolactin, œestradiol and progesterone data obtained from short and long laying persistency hens and this stage effect was also significant for œstradiol and progesterone data obtained from broody and non-broody hens. Otherwise, plasma LH concentrations decreased slightly but significantly throughout the laying year in all hens but no significant differences between physiological states were observed, although the decrease was more pronounced in the hens that went out-of-lay. Plasma progesterone concentrations remained stable throughout in laying hens but decreased significantly in broody and/or out-of-lay hens. Plasma prolactin concentrations were maximal between the 5 th and 12th week of egg production and the levels observed in laying hens that did not become broody or had a long laying persistency were twice those measured in broody and/or out-of-lay hens. In the meantime, plasma œstradiol concentrations were lower and stable in laying hens, whereas they were higher during the first half of the productive period in broody and short laying persistency hens. These results suggest that, under our experimental conditions, the hormonal profiles of prolactin and œstradiol for a given hen during the first 10 weeks of the laying cycle may provide predictive information for future changes in its physiological status. The inverse relationship that was observed here between high early plasma concentrations of œstradiol and laying persistency is original. In addition, the relationship between the ability to express broodiness and high and low early plasma concentrations of cestradiol and prolactin, respectively, in hens submitted to preventive broody treatment has not been reported previously. Furthermore, it seems clear that high initial concentrations in prolactin, far from exerting any deleterious effects on egg production are closely associated with a longer persistency of egg laying.
\end{abstract}

turkey hens / LH / prolactin / ovarian steroids / laying persistency / broodiness expression

*These results were partially presented at the Vth International Symposium on Avian Endocrinology, Edinburgh, Scotland (Sept 1992). 


\begin{abstract}
Résumé - Variations hormonales associées à l'expression du comportement d'incubation et la persistance de ponte durant un cycle de production chez la dinde (Meleagris gallopavo). Les évolutions de la production d'œufs, de l'expression du comportement d'incubation et des concentrations plasmatiques de $\mathrm{LH}$, prolactine, œestradiol et progestérone sont observées au cours d'une première période de production chez la dinde. Respectivement 33 et $25 \%$ des dindes ont pu être classifiées a posteriori selon qu'elles aient exprimé le comportement de couvaison ou interrompu la ponte. Un pourcentage important (67\%) des femelles, qui ont interrompu la ponte, ont antérieurement exprimé la couvaison. Globalement, un effet significatif $(p<0,05)$ du facteur "état physiologique " est mis en évidence lorsque les taux de prolactine, de progestérone et d'cestradiol mesurés chez les dindes ayant ou non une bonne persistance de ponte sont comparés, alors qu'il est significatif pour les taux de progestérone et d'cestradiol mesurés chez les dindes couveuses ou non-couveuses. Par ailleurs, les concentrations plasmatiques de LH diminuent graduellement pendant la période de production et cette décroissance est plus accentuée chez les dindes qui ont interrompu la ponte toutefois, aucune différence significative n'est mise en évidence. Les concentrations plasmatiques de progestérone restent stables chez les dindes pondeuses mais diminuent significativement chez les dindes couveuses etlou en arrêt de ponte. Les concentrations plasmatiques de prolactine sont maximales depuis la $5^{e}$ jusqu'à la $12^{e}$ semaine de production et les taux mesurés durant cette période sont plus élevés chez les dindes pondeuses qui n'ont pas exprimé la couvaison et qui ont eu une bonne persistance de ponte. Parallèlement, les concentrations plasmatiques d'œstradiol sont plus faibles mais stables chez les dindes pondeuses, alors qu'elles sont plus élevées durant la première moitié de la période expérimentale chez les dindes qui arrêtent prématurément leur production. Ces résultats suggèrent que, dans nos conditions expérimentales, l'observation des profils plasmatiques de prolactine et d'oestradiol au cours des 10 premières semaines de production pourrait être un prédicteur de variations potentielles ultérieures de l'état physiologique, chez la dinde. La corrélation mise en évidence entre l'évolution des taux d'œestradiol et la persistance de ponte, de même que l'évolution inverse des taux circulants d'œestradiol et de prolactine n'ont jamais été décrites auparavant. Par ailleurs, il apparaît que, dans nos conditions expérimentales, des taux élevés de prolactine, loin d'avoir des effets inhibiteurs sur la production d'œufs, sont associés à une meilleure persistance de l'activité de reproduction.
\end{abstract}

dinde / LH / prolactine / stéroïdes ovariens / persistance de ponte / incubation

\section{INTRODUCTION}

High plasma prolactin and low plasma LH concentrations are associated with the expression of broodiness in galliforms (Cogger et al, 1979; Sharp et al, 1979; Burke and Dennison, 1980; El Halawani et al 1980; Proudman and Opel, 1981; Harvey and Bedrak, 1984; Zadworny et al 1985) whereas an increase in prolactin level only occurs at the end of the incubation period and remains high during the rearing of the young in columbiforms (Goldsmith et al, 1981). Results from an early study suggested that prolactin induced broodiness in birds (Riddle et al, 1935). However, more recent studies using high doses of heterologous hormones (oPRL) brought controversial results (Opel and Proudman, 1980; El Halawani et al,
1986; Sharp et al, 1988; Youngren et al, 1991). Otherwise, a pharmacologically induced decrease in prolactin levels affects the expression of incubation behaviour (EI Halawani et al, 1983; Guémené and Etches, 1989; Sharp et al, 1989) whereas the readiness to incubate after nest-deprivation does not appear to depend on high plasma prolactin concentrations (El Halawani et al, 1980; Goldsmith et al, 1984; Richard-Yris et al, 1993). On the other hand, ovine prolactin has been reported to induce ovarian regression (Opel, 1971; Opel and Proudman, 1980) and to inhibit LH-stimulated steroidogenesis (Camper and Burke, 1977; Zadworny et $a /, 1989)$. Depending on the period of treatment, it may also delay the photoinduced rise in LH (El Halawani et al, 1991) and decrease the rise in $\mathrm{LH}$ induced by nestdeprivation in incubating hens (Sharp et al, 
1988). In addition, the injection of anti-prolactin serum increased plasma LH concentrations of incubating bantam hens (Lea et al, 1981) while high levels of prolactin blocked the post-castration increase in circulating $\mathrm{LH}$ in incubating hens (Zadworny and Etches, 1987). All these data strongly suggest therefore that prolactin exerts direct and/or indirect antigonadotrophic actions, while a causal relationship between an increase in plasma prolactin concentrations and the expression of broody behaviour has not yet been fully established.

The stimulatory effect of long photoperiods on $\mathrm{LH}$ secretion in birds including turkeys is well established (Follet and Davis, 1975; Godden and Scanes, 1977; Scanes et al, 1977). In the meantime, a large increase in plasma prolactin levels is associated with the onset of egg-production and the concurrent high plasma $\mathrm{LH}$ concentrations in hens of a high egg-producing strain (Etches and Cheng, 1982), but not in hens of a low egg-producing strain (Burke and Dennison, 1980). The physiological significance of this increase in prolactin is not known. It does not seem to be related to the expression of broodiness since it is observed in both broody and non-broody hens (Etches and Cheng, 1982) and no differences in basal plasma prolactin concentrations were observed between broody and non-broody hens (Bacon et al, 1983). The photoinduced increase in $\mathrm{LH}$ induces a rise in œstrogens (Bajpayee and Brown, 1972; Wineland and Wentworth, 1975) and in progesterone (Mashaly and Wentworth, 1974; Godden and Scanes, 1977). In addition, changes in the circulatory level of these steroids have been reported to be associated with the changes in physiological states: laying, incubating and out-of-lay (Guémené and Williams, 1992).

The objects of the present study were, therefore, to further increase knowledge about changes in the concentrations of plasma LH, prolactin, progesterone and œstradiol throughout the first laying period of turkey hens submitted to a preventive broody treatment and to further study the relationships with the occurrence of broodiness expression and with the persistency of egg laying under specific experimental conditions.

\section{MATERIALS AND METHODS}

\section{Animals}

Thirty-six medium white turkey hens (Betina, 56250 Saint Nolff, Elven, France) aged 29 weeks, were randomly allocated to 3 pens with wood shaving on the floor ( $n=12$ per pen). They were raised under a $6 \mathrm{~h}$ photoperiod and thereafter exposed to a stimulatory photoperiod of $14 \mathrm{~h}$ until week 16 (lights on from 3.00 to $17.00 \mathrm{~h}$ ) and of 15 $\mathrm{h}$ thereafter (lights on from $2.00 \mathrm{~h}$ ). The minimum light intensity was 50 lux. They were fed a commercial diet provided ad libitum and had free access to water. Each pen was equipped with 4 nests to which access was controlled automatically. The hens were managed according to commercial practice and were not therefore allowed to incubate eggs. Furthermore, broodiness was partially prevented by frequent egg collections and the use, after the peak of lay (4th week of egg production), of regular nest ejections with a maximum of 14 ejections per day as described previously (Guémené, 1990a).

\section{Experimental approach}

Egg production and broodiness records were obtained daily for a 27 -week production period from the onset of lay of the flock. The physiological stage (laying; broody; out-of-lay) was determined as follows. Broody hens were identified by twice daily inspections of the nest $(9.00$ and 16.00 h) as described previously (Guémené and Etches, 1990). Hens that were present on the nest at both tests and had no egg present in the oviduct at the second test were classified as broody. Identification of out-of-lay hens was carried out by oviducal palpation and measurement of the pelvic bone gap on weeks $2,8,12,17$ and 26 . 
Blood samples $(5 \mathrm{ml})$ were taken weekly from a wing vein into an heparinized syringe. Plasma was separated from blood by centrifugation at $2000 \mathrm{~g}$ for $10 \mathrm{~min}$ at $4^{\circ} \mathrm{C}$ and kept at $-20^{\circ} \mathrm{C}$ until required for radioimmunoassay for $\mathrm{LH}$, prolactin, progesterone and œstradiol. The first sample was taken $12 \mathrm{~d}$ after photostimulation just prior to egg production, which started to occur at 31 weeks of age, and weekly thereafter. Sampling was carried out between 3 and $1 \mathrm{~h}$ before the lights went off in order to minimise the possibility of sampling hens during the preovulatory peaks.

\section{Radioimmunoassays}

\section{LH}

Plasma were assayed in triplicate 100 or $50 \mu \mathrm{l}$ samples according to Sharp et al (1987) using fraction PRC-AE1-S-1 as labelled hormone and standard, and the anti LH 3-3 as antiserum. The validation of this assay for measuring turkey $\mathrm{LH}$ has been reported previously (Guémené and Williams, 1992). The mean intraassay variation was $12.6 \%$ and the interassay variation for the 2 assays needed for this study was $10.8 \%$.

\section{Prolactin}

Plasmas were assayed in triplicate $100 \mu \mathrm{l}$ samples following the method of Etches and Cheng (1982), but using TPRL provided by Proudman and Opel (1981) as labelled hormone and standard and the anti-tPRL-2-B3 provided by Etches and Cheng (1982) as antiserum. The mean intraassay variation was $7.6 \%$ and the interassay variation for the 2 assays needed for this study was $9.4 \%$.

\section{Progesterone}

Progesterone was assayed using the method described by Duplaix et al (1981). The mean intraassay variation and the interassay variation for the 5 assays needed for this study were $3.5 \%$ and $15.2 \%$, respectively.

\section{Estradiol}

Plasma concentrations of cestradiol were assayed in duplicate $0.6 \mathrm{ml}$ plasma samples according to
Etches et al (1984). The mean intraassay variation and the interassay variation for the 5 assays needed for this study were $3.7 \%$ and $17.8 \%$, respectively.

\section{Statistical analysis}

The endocrinological data were analysed using a 2-way ANOVA (time and physiological stage effects (broody vs non-broody and out-of-lay vs laying at week 26) and Fisher PLSD (protected least significant difference) post hoc test if appropriate $(P \leq 0.05$, ANOVA). The standard error of the mean was used to express data variability.

\section{RESULTS}

\section{Husbandry and behavioural observations}

The onset of egg production occurred 2 weeks after exposure to the stimulatory photoperiod and during the week following the first blood sampling. The peak of production occurred 2 weeks after the first egg was laid (fig 1). Egg production declined gradually thereafter throughout the experiment, but a larger decrease was observed between the 12th and the 15th week of production.

Nearly $33 \%$ of the hens ( 10 out of 36 ) were identified as broody at least once during the reproductive cycle and from 3 to $12 \%$ of the hens were identified as broody each week from the 4 th week until the end of the production period (fig 1). All hens studied in this experiment were laying on weeks 2, 8 and 12 whereas $14 \%$ (5 out of 36 ) and $25 \%$ (9 out of 36) were out-of-lay in weeks 17 and 26 , respectively. None of the hens that were out-of-lay on week 17 resumed egg production afterwards. A high percentage $(67 \%)$ of the hens that became out-of-lay had previously been identified as broody. 


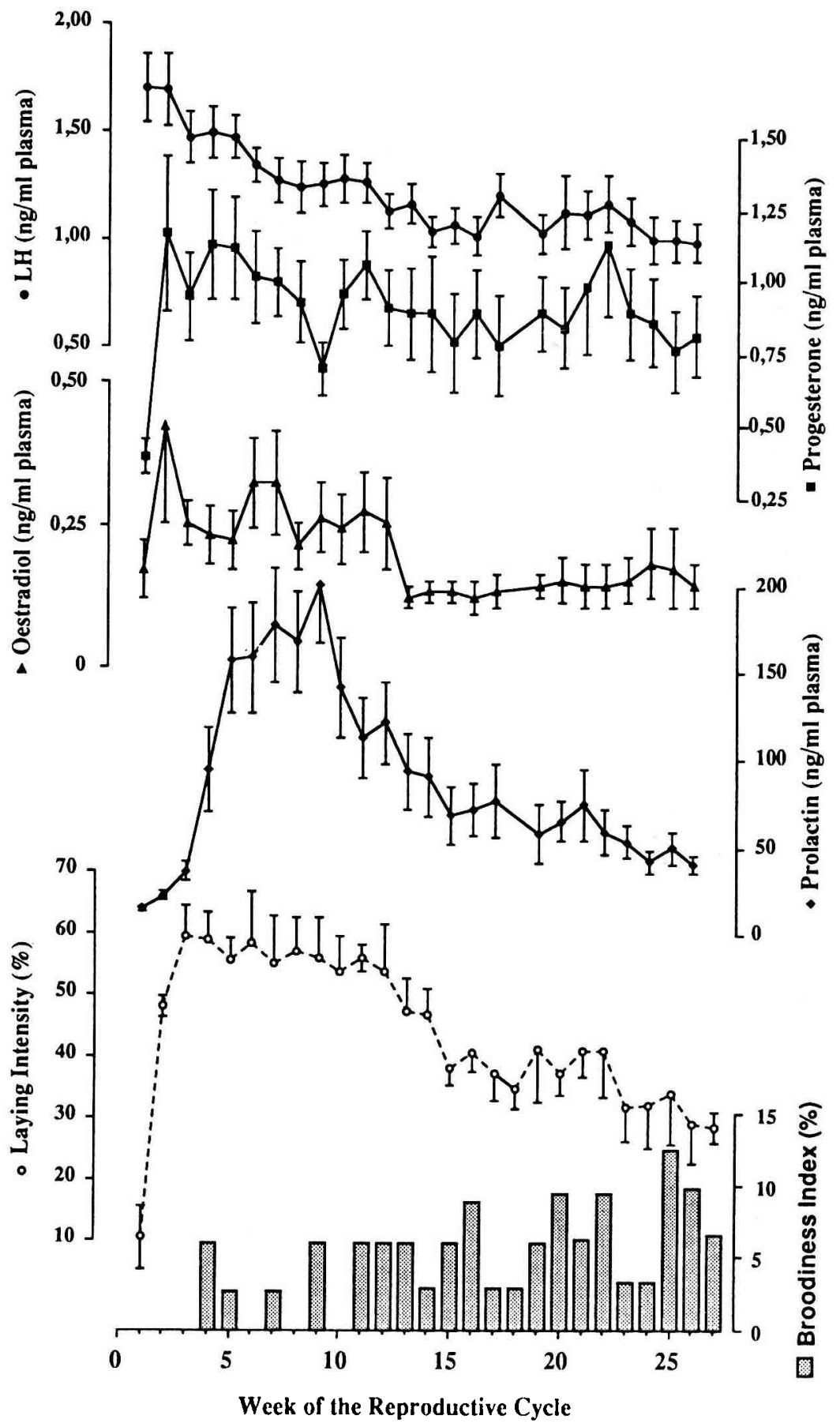

Fig 1. Plasma concentrations ( $\mathrm{ng} / \mathrm{ml})$ of $\mathrm{LH}(--)$, progesterone (- $\longrightarrow$ ), œstradiol $(-\mathbf{\Delta}-)$ and prolactin (- -), egg production (---O---) and broodiness index ( ing period (means \pm SEM). 


\section{Endocrinological data}

The plasma concentrations of 4 hormones in the turkey hens throughout the first laying year are shown in figures 1 and 2 and results of the statistical analysis are reported in tables I and II. Plasma LH concentrations were maximal at the onset of egg production and declined progressively and significantly $(P<0.01)$ thereafter. No significant effect of the physiological stage $(P>0.05$; broody versus non-broody or out-of-lay versus laying) was found, whereas a significant interaction $(P<0.05)$ between the time and physiological stage in the comparison of the out-of-lay versus laying hens was found $(p<$ 0.05 ). This is due to the presence of higher levels of $\mathrm{LH}$ in the plasma during the first few weeks of egg production and lower levels later (from week 20) for the out-of lay hens.

The plasma concentrations of prolactin changed significantly $(p<0.01)$ throughout the reproductive cycle. Initially, they were low but they then increased to reach a maximum 7-12 weeks after photostimulation and declined thereafter. However, there were clear differences from the 5 th to the 12th week of the reproductive cycle between hens which became broody and those which did not exhibit any incubation behaviour, and between hens showing a long laying persistency and those which went out-oflay before the end of the experiment. The plasma prolactin concentrations measured were lower in broody than in non-broody hens during this initial period and significantly lower $(p<0.01)$ throughout the repro-

Table I. Summary of $p$ values obtained by ANOVA for time and physiological stage effects on 4 hormones of turkey hens with short or long laying persistency.

\begin{tabular}{llcc}
\hline Variable & \multicolumn{3}{c}{ Factor } \\
\cline { 2 - 3 } & Time & Physiological stage & Interaction \\
\hline & & & \\
LH & 0.001 & 0.60 & 0.03 \\
CEstradiol & 0.10 & 0.003 & 0.41 \\
Progesterone & 0.33 & 0.001 & 0.87 \\
Prolactin & 0.003 & 0.001 & 0.59 \\
\hline
\end{tabular}

Table II. Summary of $p$ values obtained by ANOVA for time and physiological stage effects on 4 hormones of broody or non-broody hens.

\begin{tabular}{llcc} 
Variable & \multicolumn{3}{c}{ Factor } \\
\cline { 2 - 3 } & Time & Physiological stage & Interaction \\
\hline L.H & 0.001 & 0.95 & 0.97 \\
CEstradiol & 0.12 & 0.003 & 0.85 \\
Progesterone & 0.43 & 0.001 & 0.94 \\
Prolactin & 0.001 & 0.24 & 0.85
\end{tabular}



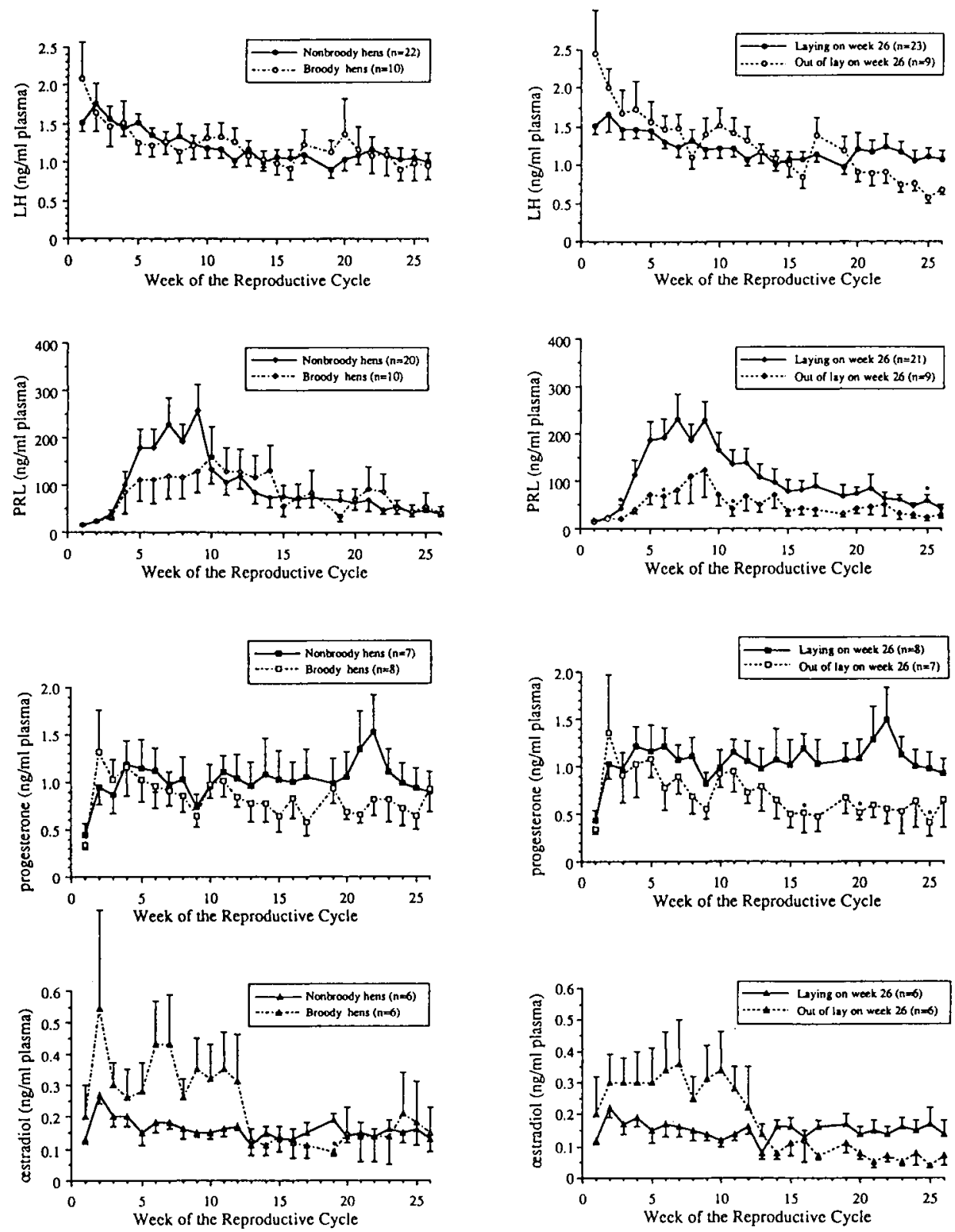

Fig 2. Plasma concentrations $(\mathrm{ng} / \mathrm{ml})$ of $\mathrm{LH}$, prolactin, progesterone and œstradiol in turkey hens which have been classified broody at least once (open symbols and dashed line) or not (closed symbols and solid line) and of turkey hens with short (open symbols and dashed line) or long laying presistency (closed symbols and solid line) during the first laying period (means \pm SEM). * $P<0.05$ for comparison at a specific time (protected least significant difference procedure). 
ductive cycle for the hens which went outof-lay compared with hens which displayed good persistency of lay.

Plasma œestradiol concentrations reached a maximum at the 2 nd week of lay and remained higher until week 12 . Afterwards, these concentrations were much lower than those measured during the first part of the laying year. A significant difference in the changes in œstradiol concentrations in relation to the physiological status $(p<0.01)$ was observed in both comparisons (broody versus non-broody and out-of-lay versus laying). The plasma concentrations of œstradiol were quite stable in non-broody or in hens which showed good persistency of laying. On the other hand, the broody or the out-of-lay hens displayed high œstradiol concentrations in plasma during the first half of the experiment. These concentrations were lower in out-of-lay than in laying hens after the 17th week of egg production, while they were comparable in broody versus nonbroody hens except on week 19.

The plasma concentrations of progesterone measured in turkey hens throughout the laying year were lowest in the first experimental sample and higher thereafter. However, no significant time effect $(p>0.05)$ was found in this experiment. On the other hand, significant differences between the physiological states ( $p<0.01$; broody versus non-broody and out-of-lay versus laying) were found. This was due to the decrease in plasma progesterone concentrations with time observed in the broody and out-of-lay hens.

\section{DISCUSSION}

The findings of the present study confirm knowledge of the changes in plasma hormone levels associated with different physiological states in turkey hen. The passage from short to long photoperiods stimulates the secretion of LH (Godden and Scanes,
1977; Burke and Dennison 1980; Lea and Sharp, 1982; El Halawani et al, 1984), and in this experiment the onset of lay which followed photostimulation was associated with higher $\mathrm{LH}$ concentrations. A tendency for greater initial concentrations was observed in the hens that were the least persistent layers. Although we did not record individual egg production in this experiment, data from another study using hens of a similar strain (Guémené, 1990b) showed that short persistency hens were no more precocious than long persistency hens. The larger decrease in plasma LH concentrations which occurred during the last few weeks of this experiment in the short-persistency hens is consistent with egg-laying disruption. A decline in circulating $\mathrm{LH}$ throughout the laying year was also observed in long persistency laying turkey hens. Such a decrease has not been reported previously (Lea and Sharp, 1982; El Halawani et al, 1984). However, it did not result in a decrease in ovarian steroidogenic activity as measured by œestradiol and progesterone secretions.

The increased concentrations of plasma œstradiol and progesterone occurring at the onset of the laying year is attributable to the stimulatory effects of increasing plasma $\mathrm{LH}$ concentrations on the ovary (for review, Sharp, 1989). Progesterone secretion does not increase until the ovary is fully developed (Williams and Sharp, 1977) as the chief site of synthesis is the granulosa cell layer of the largest follicle of the hierarchy (Imai and Nalbandov, 1978; Culbert et al 1980; Etches and Duke, 1984). The observation that plasma progesterone concentrations reached a maximum at the peak of egg-laying is consistent with this idea. The decrease in plasma progesterone concentrations throughout the laying year in broody and out-of-lay hens is clearly related to their physiological states. Mashaly and Wentworth (1974), Mashaly et al (1976), and Scanes et al (1979) also reported a similar progressive decrease in plasma proges- 
terone concentrations during the first year of lay in hens which showed a low rate of egg production.

An increase in plasma prolactin concentrations associated with the peak of lay has been reported previously by Etches and Cheng (1982). However a such change was not observed previously by Burke and Dennison (1980). The results of the present study therefore support the findings of Etches and Cheng (1982). Otherwise, we found a smaller increase in plasma prolactin concentrations in broody than in non-broody hens, and in short persistency than in long persistency hens over a 5-week period following the peak of lay. A high percentage of the hens that ceased egg laying earlier had been classified broody on a prior occasion and we cannot exclude the possibility that other hens may have expressed some symptoms which were not observed under the present experimental conditions. Lower plasma prolactin concentrations in hens that were to express broodiness later is indeed a puzzling observation. Furthermore in another experiment conducted in a different room with hens not submitted to broody treatment, broodiness expression was associated with high plasma prolactin levels (Bédécarrats et al, 1993). The present observation does not exclude however an increase in prolactin concurrently with broodiness expression. Similarly, Bacon et al (1983) did not find any difference in the base-line concentrations of plasma prolactin between hens that became broody and those which did not. We suggest that the hens that became broody were probably more inclined to stay longer in the nest and were therefore more often submitted to automatic nest ejections combined with frequent egg collection. We cannot exclude that certain hens are more sensitive to preventive treatments in terms of lowering their circulating concentrations of prolactin without preventing broodiness expression. It is clear from this study that low circulatory levels of prolactin do not prevent these hens becoming broody. Likewise, icv perfusions of ovine prolactin in turkey hens induce a drop in circulating levels of prolactin while persistent nesting activity was displayed (Youngren et al, 1991). We cannot exclude therefore that under our experimental procedure these hens had low circulating prolactin levels but high central levels of prolactin.

Alternatively, the observed difference in plasma prolactin concentrations between long and short laying persistency hens may perhaps clarify the differing results obtained with hens from a high producing strain (Etches and Cheng, 1982) and with hens from a low producing strain (Burke and Dennison, 1980). Indeed, the present data suggest the existence of a proportional relationship between laying persistency and the presence of high plasma concentrations in prolactin between the 5 th and 11 th week of production. On the other hand, prolactin has been reported to inhibit LH secretion and to exert antigonadal effects in turkey hens (Opel and Proudman, 1980; Zadworny and Etches, 1987; El Halawani et al, 1991). However, one of the major problem remains the heterologous nature of the prolactin used in all these studies and it is likely that these preparations contain other pituitary contaminants and not impossible that heterologous prolactins have different affinities for the avian receptor and even elicit different responses.

Selection against broodiness and selection for increased egg production probably affect different endocrinological mechanisms. For the strain used in the present study, a decrease in the sensitivity to high peripheral concentrations of prolactin as a result of the selection process cannot be excluded since high levels were associated with egg laying persistency and not with broodiness expression. Furthermore, the differences found in prolactin concentrations did not correspond to any large differences in $\mathrm{LH}$ concentration. The present data 
also confirm previous studies (Lea and Sharp, 1982; Bacon et al, 1983; Zadworny et al, 1986) showing that large increases in plasma prolactin concentrations do not anticipate the development of gonadal regression and/or photorefractoriness in turkey hens unlike some wild galliform species (Stokkan et al, 1988) or other wild species of birds (Dawson and Goldsmith, 1983).

As turkey hens come into lay, increasing concentrations of œstrogens enhance the release of prolactin (El Halawani et al, 1983; El Halawani et al, 1986; Saeed and El Halawani, 1986). It was observed in the present experiment that the changes in prolactin and œstradiol concentrations were inversely related. Moreover, the decrease in circulating prolactin in laying hens occurs independently of any change in œstradiol concentrations, therefore the facilitatory action of this steroid may become attenuated with time or counteracted by another mechanism. On the other hand, prolactin has been reported to inhibit the secretion of cestradiol from the small follicles (Zadworny et al, 1989) which are the major source of this steroid (Robinson and Etches, 1986). Therefore, the observed high concentrations of prolactin in long persistency hens may be the cause of their lower concentrations of plasma œstradiol. Alternatively, the high initial level of œstradiol may be the cause of early cessation of egg laying through a negative feed-back. These low persistency hens also displayed a decrease in progesterone concentrations with time and the largest ovarian follicle is the main source of plasma progesterone in birds (Imai and Nalbandov, 1978; Etches and Duke, 1984). We cannot exclude therefore that these hens were always poor layers having a full set of maturing yellow-yolky follicles producing œstradiol and less or no fully mature pre-ovulatory follicles producing progesterone.

We conclude that, under our experimental conditions, information on hormonal changes such as prolactin and œstradiol secretion at the beginning of the laying year may provide predictive information on the laying persistency. The inverse relationship that was observed here between high early plasma concentrations of œstradiol and laying persistency has not been reported previously. Furthermore, it appears that the hens that had a longer egg-laying persistency had slightly lower levels of LH during the first 5 weeks of lay. In addition, the relationship between the ability to express broodiness and high and low early plasma concentrations of œstradiol and prolactin respectively in hens submitted to preventive broody treatment has not been reported previously either. Furthermore, it seems clear that high initial concentrations in prolactin, far from exerting any deleterious effects on egg production are closely associated with a longer persistency of egg laying.

\section{ACKNOWLEDGMENTS}

The cooperation of Betina, in providing financial support, was greatly appreciated. Our thanks are extended to PJ Sharp for supplying the materials used in the LH assays and RJ Etches and JA Proudman for supplying the materials used in the prolactin and/or œstradiol assays. We are indebted to MT Durand, M Garreau-Mills, B Gaultier and S Nevoit for expert technical assistance.

\section{REFERENCES}

Bacon WL, Burke WH, Nestor KE, Brown KI (1983) Influence of genetic increases in egg production on traits associated with broodiness in turkeys. Poult Sci 62, 2460-2473

Bajpayee DP, Brown KI (1972) Effect of photoperiodicity on the circulating levels of cestrogens, corticosterone, calcium and free fatty acids in female domestic turkeys (Meleagris gallopavo). Poult Sci $51,1157-1165$

Bédécarrats G, Guémené D, Richard-Yris MA (1993) Relationship between rearing conditions, concen- 
tration in prolactin and incubation behaviour in turkey hens (Meleagris gallopavo). Proc Int Conf Hormone, Brain and Behaviour, Tours, France 19-20

Burke WH, Dennison PT (1980) Prolactin and luteinizing hormone levels in female turkeys (Meleagris gallopavo) during a photoinduced reproductive cycle and broodiness. Gen Comp Endocrino/ 41, 92-100

Camper PM, Burke WH (1977) The effects of prolactin on the gonadotropin induced rise in senum estradiol and progesterone on the laying turkey. Gen Comp Endocrino/ 32, 72-77

Cogger EA, Burke WH, Ogren LA (1979) Serum luteinizing hormone, progesterone and cestradiol levels in relation to broodiness in the turkey (Meleagris gallopavo). Poult Sci 58, 1335-1360

Culbert J, Hardie MA, Wells JW, Gilbert AB (1980) Effect of ovine $\mathrm{LH}$ on the progesterone content of the granulosa cells in preovulatory follicles of the domestic fowl (Gallus domesticus). J Feprod Fertil 58, 449453

Dawson A, Goldsmith AR (1983) Plasma prolactin and gonadotrophins during gonadal development and the onset of photorefractoriness in male and female starlings (Sturnus vulgaris) on artificial photoperiods. J Endocrinol 97, 253-260

Duplaix M, Williams JB, Mongin P (1981). Effects of an intermittent lighting schedule on the time of egg-laying and the levels of luteinizing hormone, progesterone and corticosterone in the plasma of the domestic hen. J Endocrinol 91, 375-383

EI Halawani ME, Burke WH, Dennison PT (1980) Effect of nest deprivation on serum prolactin level in nesting female turkeys. Biol Reprod 23, 815-819

El Halawani ME, Silsby JL, Behnke EJ, Fehrer SC (1983) Reinitiation of ovulatory cycles in incubating female turkeys by an inhibitor of serotonin synthesis, $\rho$ chlorophenylalanine. Biol Reprod 28, 221-228

El Halawani ME, Silsby JL, Behnke EJ, Fehrer SC (1984) Effect of ambiant temperatures on serum prolactin and luteinizing hormone levels during the reproductive life cycle of the female turkey (Meleagris ga/lopavo). Biol Reprod 30, 809-815

El Halawani ME, Silsby JL, Behnke EJ, Fehrer SC (1986) Hormonal induction of broodiness in ovariectomized fernale turkeys (Meleagris gallopavo). Biol Reprod $35,59-67$

EI Halawani ME, Silsby JL, Youngren OM, Phillips RE (1991) Exogenous prolactin delays photo-induced sexual maturity and suppresses ovariectomy-induced luteinizing hormone secretion in the turkey (Meleagris gallopavo). Biol Reprod 44, 420-424

Etches RJ, Cheng KW (1982) A homologous radioimmunoassay for turkey prolactin: changes during the reproductive and ovulatory cycle. Poult Sci 61 , 1354-1362

Etches RJ, Duke CE (1984) Progesterone, androstenedione and cstradiol content of theca and granulosa tissues of four the largest ovarian follicles during the ovulatory cycle of the hen (Gallus domesticus). $J$ Endocrinol 103, 71-76

Etches RJ, Williams JB, Rzasa J (1984) Effects of corticosterone and dietary changes in the hen on ovarian function, plasma $\mathrm{LH}$ and steroids and the responses to exogenous LH-RH. J Reprod Fertil 70, $121-130$

Follett BK, Davis DT (1975) Photoperiodicity and the neuroendocrine control of reproduction in birds. $I n$ : Advances in Avian Physiology (M Parker, ed) Symp Zool Soc Lond 35, 199-224

Godden PMM, Scanes CG (1977) Effect of photoperiod on gonadotrophin concentrations in domestic turkeys. Br Poult Sci 18, 687-694

Goldsmith AR, Edwards C, Kopruscu M, Silver R (1981) Concentrations of prolactin and luteinizing hormone in plasma of doves in relation to incubation and development of the crop gland. J Endocrinol 90,437-443

Goldsmith AR, Burke S, Prosser JM (1984) Inverse changes in plasma prolactin and $\mathrm{LH}$ concentrations in female canaries after deprivation and reinitiation of incubation. J Endocrinol 103, 251-256

Guémené D (1990a) Broodiness treatments and laying performances in turkey hens. Proc VIIIth Eur Poult Conf, Barcelona, Spain 607-610

Gumémené D (1990b) Effect of changing lighting programs at various ages on laying performance in turkey hens (Meleagris gallopavo) housed in cages or in floor pens. In: Control of Fertility in Domestic Birds (JP Brillard, eds) 233-242

Guémené D, Etches RJ (†989) Endocrinological and behavioural effects of $p$-chlorophenylalanine (PCPA) oral administrations to broody turkey hens (Meleagris gallopavo). Reprod Nutr Devel 29, 469-476

Guémené D, Etches RJ (1990) Changes in the plasma concentrations of prolactin, $\mathrm{LH}$, progesterone and $D-(\beta)$-hydroxybutyrate in turkey hens (Meleagris ga/lopavo), during treatment for broodiness under commercial conditions. Br Poul Sci 31, 847-857

Guémené D, Williams JB (1992) Comparison of the basal and luteinizing hormone-releasing hormone (LH-RH) induced luteinizing hormone (LH) release by perifused hypophyses from turkey hens (Meleagris gallopavo) at different physiological stages. Br Poultr Sci 33, 153-163

Harvey S, Bedrak E (1984) Endocrine basis of broodiness in poultry. Reprod Biol Poultr, Proc XVIIth Poult Sci Symp (FJ Cunningham, PE Lake, D Hewitt, eds). Br Poutr Sciltd, 111-132

Imai K, Nalbandov AV (1978) Plasma and follicular steroid levels of laying hens after the administration of gonadotropins. Biol Reprod 19, 779-784

Lea RW, Dods ASM, Sharp PJ, Chadwick A (1981) The possible role of prolactin in regulation of nesting behaviour and the secretion of luteinizing hormone in broody bantams. $J$ Endocrinol 91, 89-97 
Lea RW, Sharp PJ (1982) Plasma prolactin concentrations in broody turkeys: lack of agreement between homologous chicken and turkey prolactin radioimmunoassays. Br Poultr Sci 23, 451-459

Mashally MM, Wentworth BC (1974) A profile of progesterone in turkey sera. Poult Sci 53, 2030-2035

Mashally MM, Birrenkott GP, El Begearni MM, Wentworth BL (1976) Plasma LH and progesterone concentrations in the turkey hen during the ovulatory cycle. Poult Sci55, 1226-1234

Opel $H(1971)$ Induction of incubation in the hen by brain implants of prolactin. Poult Sci 50, 1613

Opel H, Proudman JA (1980) Failure of mammalian prolactin to induce broodiness in chickens and turkeys. Poult Sci 59, 2550-2558

Proudman JA, Opel H (1981) Turkey prolactin: validation of a radioimmunoassay and measurement of changes associated with broodiness. Biol Reprod $25,573-580$

Richard-Yris MA, Chadwick A, Guémené D, GrillouSchuelke H, Leboucher G (1993) Influence of the presence of chicks and duration of nest deprivation on the ability to resume incubation behaviour in domestic hens (Gallus domesticus). Proc int Cont Hormone, Brain and Behaviour, Tours, France 153154

Riddle O, Bates RW, Lahr EL (1935) Prolactin induces broodiness in fowl. Am J Physiol 11, 352-360

Robinson FE, Etches RJ (1986) Ovarian steroidogenesis during follicular maturation in the domestic fowl (Gallus domesticus). Biol Reprod 35, 1096-1105

Saeed W, El Halawani ME (1986) Modulation of the prolactin response to thyrotropin releasing hormone by ovarian steroids in ovariectomized turkeys (Meleagris gallopavo). Gen Comp Endocrinol 62, 129-136

Scanes CG, Godden PMM, Sharp PJ (1977) A homologous radioimmunoassay for chicken follicle-stimulating hormone: observations on the ovulatory cycle. $J$ Endocrinol 73, 473-479

Scanes CG, Sharp PJ, Harvey S, Godden PMM, Chadwick A, Newcomer WS (1979) Variations in plasma prolactin, thyroid hormones, gonadal steroids and growth hormone in turkeys during the induction of egg laying and moult by different photoperiods. $\mathrm{Br}$ Poult Sci 20, 143-148

Sharp PJ (1989) Physiology of egg production. In: Recent Adv Turkey Sci (C Nixey, TC Grey, eds). Chap 3, 31-54

Sharp PJ, Scanes CT, Williams JB, Harvey S, Chadwick $A$ (1979) Variations in the concentration of plasma prolactin, luteinizing hormone, growth hormone and progesterone in broody bantam (Gallus domesticus). J Endrocrinol 80, 51-57

Sharp PJ; Dunn IC, Tabot RT (1987) Sex differences in the $\mathrm{LH}$ responses to chicken $\mathrm{LHRH}-\mathrm{I}$ and $-\mathrm{II}$ in the domestic fowl. J Endocrinol 115, 323-331

Sharp PJ, Macnamee MC, Sterling RJ, Lea RW, Ped ersen HC (1988) Relationships between prolactin, $\mathrm{LH}$ and broody behaviour in bantam hens. $J$ Endocrinol 118, 279-286

Sharp PJ, Sterling RJ, Talbot RT, Huskisson NS (1989) The role of hypothalamic vasoactive intestinal polypeptide in the maintenance of prolactin secretion in incubating bantam hens: observations using passive immunization, radioimmunoassay and immunohistochemistry. J Endocrinol 122, 5-13

Stokkan KA, Sharp PJ, Dunn IC, Lea RW (1988) Endocrine changes in photostimulated willow ptarmigan (Lagopus lagopus lagopus) and svalbard ptarmigan (Lagopus mutus hyperboreus). Gen Comp Endocrinol $70,169-177$

Youngren, OM, El Halawani ME, Silsby, JL Phillips RE (1991) Intracranial prolactin perfusion induced incubation behavior in turkey hens. Biol Reprod 44, 425430

Williams JB, Sharp PJ (1977) Comparison of plasma progesterone and plasma luteinizing hormone in growing hens from eight weeks of age to sexual maturity. J Endocrinol 75, 447-448

Wineland MJ, Wentworth BC (1975) Peripheral serum levels of $17 \beta$-estradiol in growing turkey hens. Poult Sci $53,381-387$

Zadwomy D, Etches RJ (1987) Effects of ovariectomy or force feeding on the plasma concentrations of prolactin and luteinizing hormone in incubating turkey hens. Biol Reprod 36, 81-88

Zadworny D, Walton JS, Etches RJ (1985) The relationship between plasma concentrations of prolactin and consumption of feed and water during the reproductive cycle of the domestic turkey. Poul Sci64, 401-410

Zadworny D, Walton JS, Etches RJ (1986) Effect of environment on the intake of food and water, body weight, egg production and plasma concentrations of corticosterone and prolactin in turkey hens. $\mathrm{Br}$ Poult Sci $27,639-650$

Zadworny D, Shimada K, Ishida H, Sato K (1989) Gonadotropin-stimulated estradiol production in small ovarian follicles of the hen is suppressed by physiological concentrations of prolactin in vitro. Gen Comp Endocrinol 74, 468-473 